\title{
The Effects of Bottom Ash from MSWI Used as Mineral Additions in Concrete
}

\author{
Roshazita Che Amat ${ }^{1, *}$, Khairul Nizar Ismail $^{1}$, Norazian Mohamed Noor ${ }^{1}$ and Norlia \\ Mohamad Ibrahim ${ }^{1}$ \\ ${ }^{1}$ School of Environmental Engineering, Universiti Malaysia Perlis, 02600 Arau, Perlis, Malaysia
}

\begin{abstract}
Municipal solid waste incinerators (MSWI) produce by products which can be classified as bottom and fly ashes. The bottom ash accounts for $85-90 \%$ of the solid product resulting from MSW combustion. The aimed of the present work is to study the effect of replacing partial of bottom ash were manufactured. Fresh and hardened properties of the concrete were compared in order to study the suitable cement-bottom ash replacement. Bottom ash was found to have some reactivity, but without greatly affecting the hydration process of OPC at $10 \%$ replacement. However at more than $10 \%$ replacement, the addition of bottom ash greatly affected strength.
\end{abstract}

\section{Introduction}

Nowadays, Malaysia has experienced a problem of municipal solid waste (MSW) is growing more than $91 \%$ due to increasing population and urbanization growth [1]. Municipal solid waste incinerator is the solution to release the pressure increasing of MSW. Nevertheless, by product of the incinerator were fly and bottom ash which are combined for disposal to landfill. The high cost of treatment, strategy of landfill space and also increased environmental awareness have prompted the alternative for uses the ash rather than disposal. Indeed, the recycling the waste in the concrete manufacturing is increasing due to the rising demand of infrastructures in developing countries.

Due to the construction demand was highly increased; human required a lot of concrete for construction. Concrete is used conventionally than any other man-made material in the world [3]. Even so, the use of cement as the production key ingredient is still happening. The traditional construction materials are being produced from the current natural resources. This is damaging the environment due to continuous query and depletion of pure resources [4].There is major drawbacks with respect to sustainability.

Bottom ash is mainly composed of $\mathrm{Si}, \mathrm{Fe}, \mathrm{Ca}, \mathrm{Al}, \mathrm{K}$ and others in oxides form and presents a similar composition of cement. In other countries, bottom ash was used as an aggregate substitute in road pavement [2]. This suggest that MSWI bottom ash could have pozzolonic or hydraulic behavior and its addition to concrete mix could have beneficial role in hydrated cement paste. This achievement could be a great sustainability as alternative material to cement.

\footnotetext{
*Corresponding author: roshazita@unimap.edu.my
} 


\section{Material and methods}

Bottom ash from municipal waste incinerator from Langkawi Island, Malaysia was considered. Bottom ash was subjected to dying and grinding process in order to be suitable as mineral addition in concrete. Grinding of bottom ash was carried out to reduce their size particle to less than 75 micron. Concrete mix was designed for grade 20 with constant water cement ratio $(\mathrm{w} / \mathrm{c})$ of 0.5 was manufactured. The conventional concrete or $0 \%$ composes of cement, water, aggregates and sand were considered as a control mix without bottom ash addition. In order to study the effects of MSWI bottom ash on the properties of fresh and hardened concrete, other three mixes with the same composition as control mix were cast but with $10 \%, 20 \%$ and $30 \%$ by volume replacement of cement with bottom ash as mineral addition.

Chemical composition of bottom ash and cement were determined directly by X-ray fluorescent (XRF) and were expressed as oxide percentage content. Workability of fresh concrete was measured by means of slump test. After 28 days curing, compressive strength was measured on $100 \mathrm{~mm}$ cubes. Water absorption was carried out in order to determine the percentage of water absorbed into the interconnectivity capillary pores in cement and bottom ash structure. To study the resistance to fire, the cube is initiated by burning the sample with heat rate and a predetermined time.

\section{Results and discussion}

\subsection{Chemical composition}

Table 1 below shows the Municipal solid waste contain a varies composition over time and differences between country to country, due to the variances in way of living, waste recycling process operations of a country and the ash content. This XRF reveal that several compound are present in the bottom ash. Table 1 shown the results chemical composition of cement and bottom ash for comparative purpose. Generally, the chemical and physical characterization of ash will depend on the compositions of the raw Municipal solid waste, the operational conditions, the type of incinerator and air pollution control system design. The chemical composition of cement and bottom ash shows that the major elements containing are $\mathrm{Fe}, \mathrm{Mg}$, $\mathrm{Ca}, \mathrm{Si}, \mathrm{Al}, \mathrm{K}, \mathrm{Cl}$ and $\mathrm{Na}$. In addition, $\mathrm{SiO}_{2}, \mathrm{Al}_{2} \mathrm{O}_{3}, \mathrm{CaO}, \mathrm{Fe}_{2} \mathrm{O}_{3}, \mathrm{Na}_{2} \mathrm{O}, \mathrm{K}_{2} \mathrm{O}$ are the common oxides found in ash.

The MSWI bottom ash could be reused as cement replacement materials since it contained $\mathrm{SiO}_{2}$ which is one of the main building components in cement and concrete utilizations. However, the presence of alkalis content only limit from $0.3-1.2 \%$ in cement. The presence of $2.83 \%$ of $\mathrm{K}$ in bottom ash would influence the concrete strength [5]. 
Table 1. Chemical Composition of Cement and Bottom Ash

\begin{tabular}{|c|c|c|c|}
\hline Substance & Compound & Cement & Bottom Ash \\
\hline Aluminum & $\mathrm{Al}$ & 2.90 & 4.07 \\
\hline Silicon & $\mathrm{Si}$ & 13.40 & 9.59 \\
\hline Sulfur & $\mathrm{S}$ & 3.43 & 2.45 \\
\hline Potassium & $\mathrm{K}$ & 1.12 & 2.83 \\
\hline Calcium & $\mathrm{Ca}$ & 73.47 & 63.94 \\
\hline Titanium & $\mathrm{Ti}$ & 0.34 & 1.92 \\
\hline Vanadium & $\mathrm{V}$ & 0.07 & 0.00 \\
\hline Chromium & $\mathrm{Cr}$ & 0.035 & 0.12 \\
\hline Manganese & $\mathrm{Mn}$ & 0.2 & 0.26 \\
\hline Iron & $\mathrm{Fe}$ & 4.47 & 10.00 \\
\hline Copper & $\mathrm{Cu}$ & 0.034 & 0.274 \\
\hline Strontium & $\mathrm{Sr}$ & 0.051 & 0.41 \\
\hline Zirconium & $\mathrm{Zr}$ & 0.025 & 0.12 \\
\hline Ruthenium & $\mathrm{Ru}$ & 0.20 & 0.56 \\
\hline
\end{tabular}

\subsection{Workability of concrete}

The effects on workability have been measured using slump test according to [6] and results summarized in Table 2 below. Similar range of slump (true slump) were obtained for both control concrete and concrete with addition of bottom ash.

Table 2. Result of Slump Test

\begin{tabular}{|c|c|c|}
\hline Types of concrete & Slump (mm) & Type of slump \\
\hline $\mathbf{0 \%}$ BA & 45 & True Slump \\
\hline $\mathbf{1 0 \%}$ BA & 55 & True Slump \\
\hline $\mathbf{2 0 \%}$ BA & 60 & True Slump \\
\hline $\mathbf{3 0 \%}$ BA & 77 & True Slump \\
\hline
\end{tabular}

The addition of bottom ash in mix leads to an increase in water/cement ratio which increases workability, and hence increases the flow. The very small particles and their angular surfaces increase the specific surface area of the mix, resulting in a higher water demand.

\subsection{Water absorption}

The test was carried out after completion of concrete immersed in water within a specified period. The test began with a weigh of concrete that was completed before the concrete curing in water. After completion of the mentioned concrete curing in water with the prescribed period the concrete sample will be taken and will be weighed for the second time. The difference between the original weights of the concrete used to assess the ability of concrete to absorb water. Results for the sample of concrete that has $0 \%, 10 \%, 20 \%$ and $30 \%$ converted to cement the bottom ash is shown in the Fig. 1. Subsequent tests were each mixed concrete has dried for 72 hours in an oven. Tests have been conducted on the concrete has cured to 28 days but the percentage varies replacement of cement with bottom ash which distributes to the development of a different result. 


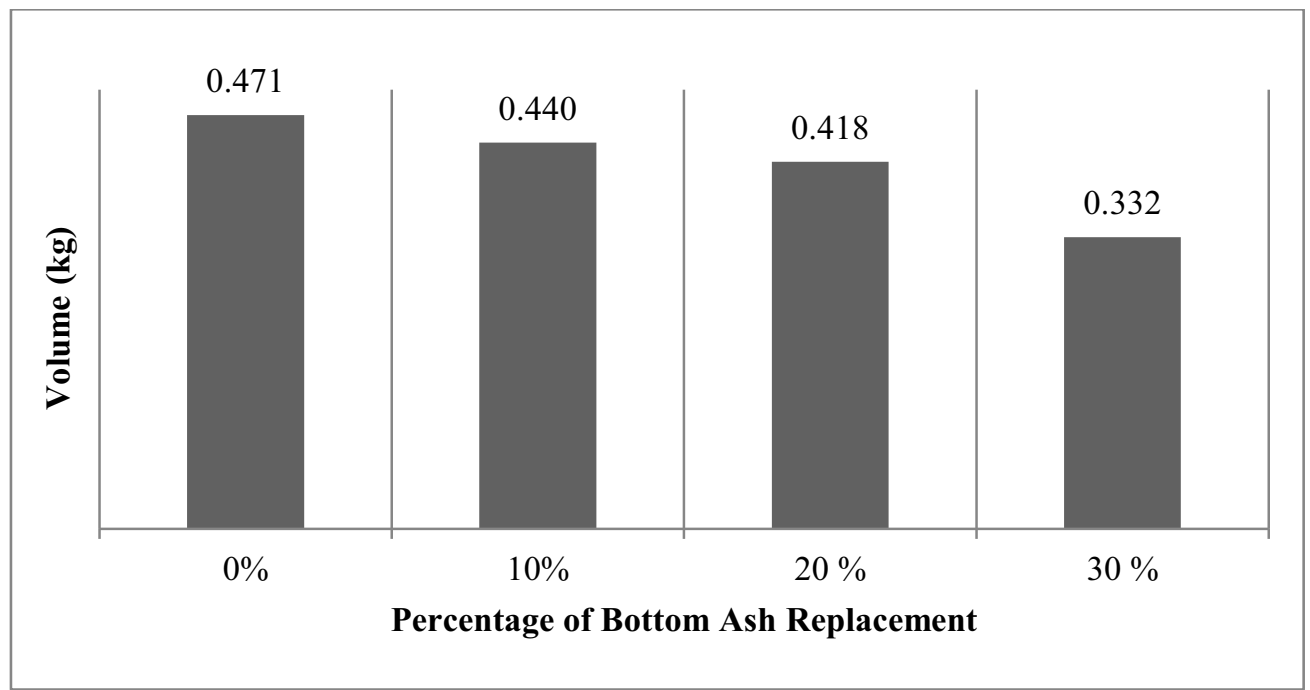

Fig. 1. Percentage of water absorption of three cubes by different percentage of bottom ash addition

\subsection{Density}

The density test was determined with water curing for 28 days and 7 days. Fig. 2 shows the average density for the preservation of water and air curing results for $0 \%, 10 \%, 20 \%$ and $30 \%$ of the bottom ash with water curing for 28 days and 7 days. Sample of $30 \%$ indicates that the most significant difference was between 7 days and 28 days was a $72 \mathrm{kN} / \mathrm{m}^{3}$ showed. Sample $20 \%$ showed a difference of as much as $43.4 \mathrm{kN} / \mathrm{m}^{3}$, while the $10 \%$ sample also showed a change of $33 \mathrm{kN} / \mathrm{m}^{3}$ and $0 \%$ showed a difference of at least $14 \mathrm{kN} / \mathrm{m}^{3}$. Sample $10 \%$ was closest to the sample $0 \%$ and $20 \%$, followed by neither the most comprehensive was $30 \%$. Sample curing time actually affects the density of concrete by increasing the mass of concrete as cement to bond strongly absorbs water and acts response as a binder to the concrete.

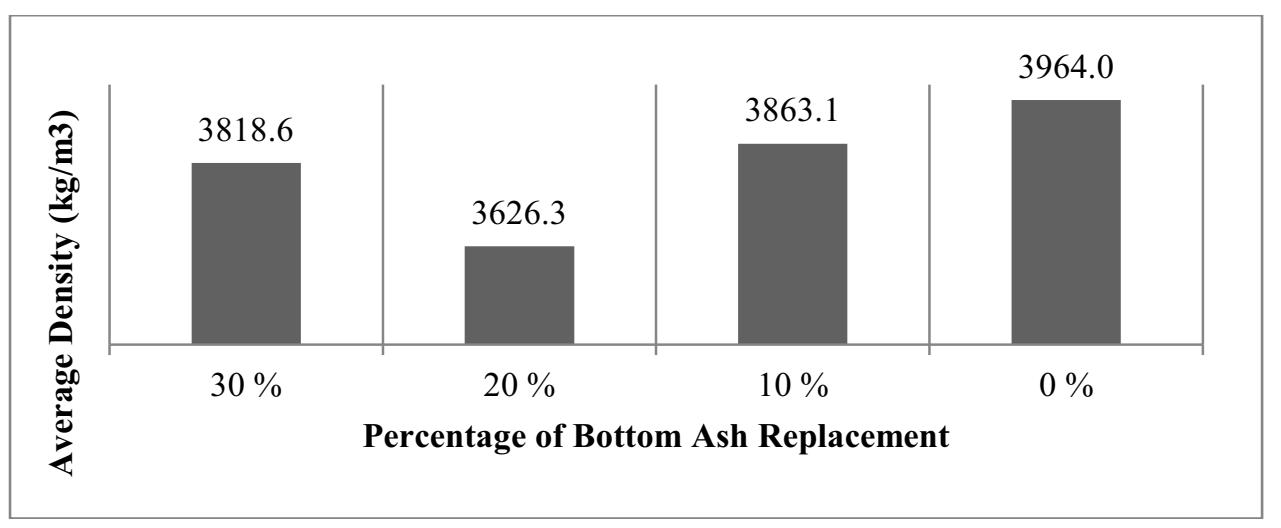

Fig. 2. Average of water curing and air curing density $\left(\mathrm{kg} / \mathrm{m}^{3}\right)$ for 28 days 


\subsection{Compressive strength}

Concrete strength was measured in accordance [7], the result of which strength can be found in Fig. 3. The concrete with only $10 \%$ of bottom ash addition achieved the compressive strength more than $20 \mathrm{MPa}$. However, at higher levels of replacement, the difference in strength is not only due to the reduced quantity of cement, but also because of the large increased in water/cement ratio. Increase in water/cement ratio would increase porosity the free water to move around through a more porous matrix.

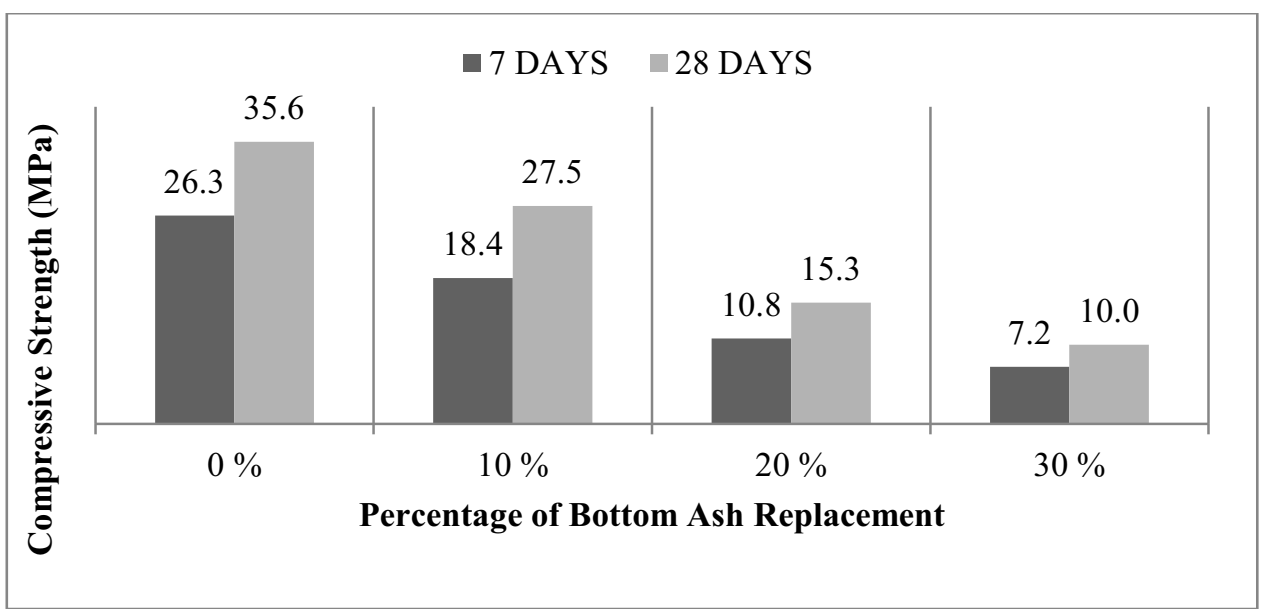

Fig. 3. Compressive strength by age of concrete

\subsection{Fire resistance}

Fire resistance tests showed strength will affect the heat or flame to move to the concrete cubes. The cubes was burned at constant temperature at $500{ }^{\circ} \mathrm{C}$ for 2 hours each sample. Fig. 4 shows the result on concrete strength before and after fire resistance testing.

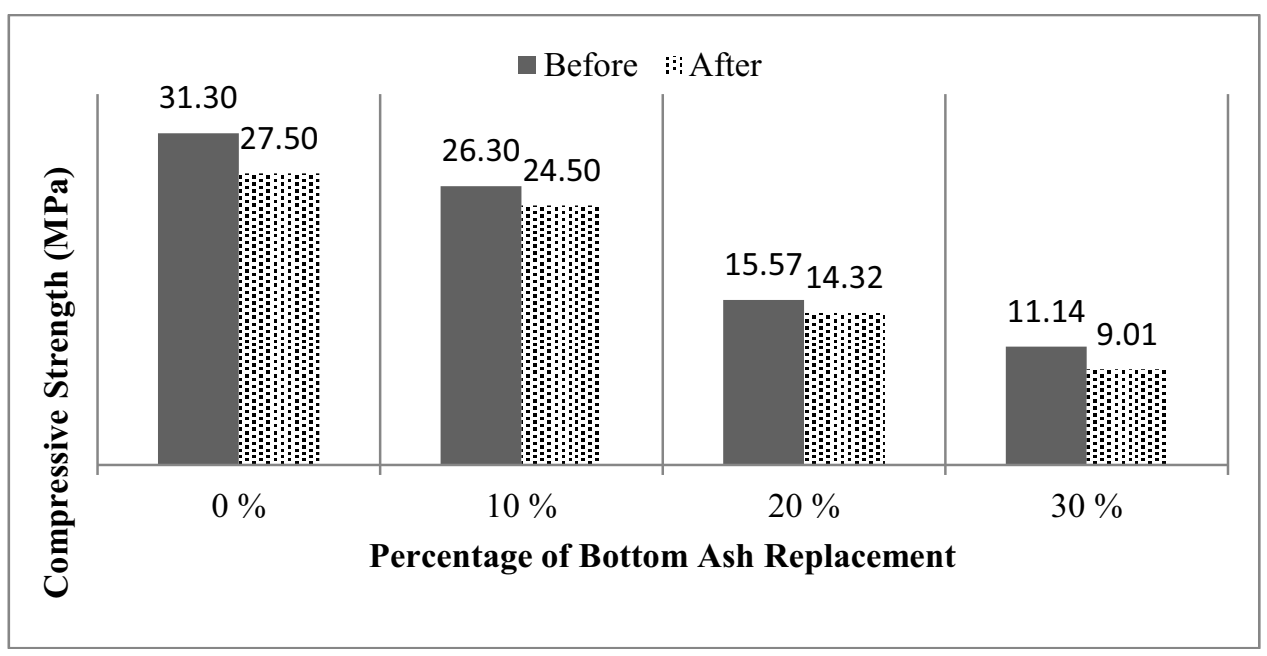

Fig. 4. Strength between sample before and after fire testing 
After exposure with fire for 2 hours, control concrete reduced strength about $12 \%$ and for concrete with addition of $10 \%$ and $20 \%$ have only 6-8 \% strength reducing. $10 \%$ produced great quality concrete for optimum strength fire resistance.

\section{Conclusion}

Tests describeb in this paper shows that bottom ash from MSW incinerator was potentially attractive as mineral aditions for concrete. The bottom ass was reactive, but far less than cement. At low percentage of replacement $(10 \%)$ was not greatly affected the properties of concrete, but at more than $20 \%$ there was a marked decrease performance. Bottom ash concret with replacement less than $20 \%$ mixture met the requirement of 28 -day compressive strength and the linear decrease of compressive strength after fire resistance testing.

This reserach was financially supported by Fundamental Research Grant Scheme from MOSTI and Universiti Malaysia Perlis.

\section{References}

1 Zamali Tarmudi, Mohd Lazim Abdullah, Abu Osman Md Tap, Jurnal Teknologi 51, 1 (2009)

2 Izquierdo Maria, Vazquez Enric, Querol Xavier, Barra Marilda, Lopez Angel, International Ash Utilization Symposium, (Center for Applied Energy Research, 2001)

3 B. Lomborg, The Skeptical Environmentalist: Measuring the Real State of the World, (Cambridge University Press, Cambridge, 2006)

4 M. Safiuddin, M. A. Jumaat, R. Hashim, M. S. Islam, Int. J. Phys. Sci., 5, 1952 (2010)

5 A.M. Neville, Properties of Concrete (Pearson, 2011)

6 British Standard 1983, Testing Concrete: Method for Determination of Slump, BS 1881: Part 102 - 1983 (British Standard Online, 2014)

7 British Standard 1983, Specification for Compression Testing Machines for Concrete, BS 1881 Part 115 - 1983 (British Standard Online, 2014) 